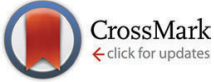

Cite this: New J. Chem., 2015 39, 7322

Received (in Montpellier, France) 19th June 2015, Accepted 15th July 2015

DOI: $10.1039 / c 5 n j 01567 g$

www.rsc.org/njc

\title{
Dioxidomolybdenum(vi) complexes with isoniazid-related hydrazones: solution-based, mechanochemical and UV-light assisted deprotonation $\dagger$
}

\author{
Višnja Vrdoljak, ${ }^{\text {a }}$ Biserka Prugovečki, ${ }^{a}$ Ivana Pulić, ${ }^{a}$ Marko Cigler, ${ }^{a}$ Dora Sviben, ${ }^{a}$ \\ Jelena Parlov Vuković, ${ }^{b}$ Predrag Novak, ${ }^{a}$ Dubravka Matković-Čalogovića and \\ Marina Cindrića
}

\begin{abstract}
Synthesis of the dioxidomolybdenum(VI) complexes $\left[\mathrm{MoO}_{2}\left(\mathrm{HL}^{\mathrm{R}}\right)(\mathrm{MeOH})\right] \mathrm{Cl}(\mathbf{1 - 3})$ was carried out by using $\mathrm{MoO}_{2} \mathrm{Cl}_{2}$ and the corresponding $\mathrm{ONO}$ aroylhydrazone ligand $\mathrm{H}_{2} \mathrm{~L}^{\mathrm{R}}$ (ligand $\mathrm{H}_{2} \mathrm{~L}^{\mathrm{R}}$ is salicylaldehyde isonicotinoylhydrazone $\left(\mathrm{H}_{2} \mathrm{~L}^{\mathrm{SIH}}\right)$, 2-hydroxy-naphthaldehyde isonicotinoylhydrazone $\left(\mathrm{H}_{2} \mathrm{~L}^{\mathrm{NIH}}\right)$, or $p$ - $\left(N, N^{\prime}\right.$-diethylamino)salicylaldehyde isonicotinoylhydrazone $\left(\mathrm{H}_{2} \mathrm{~L}^{\mathrm{Et}}{ }^{\mathrm{NSIH}}\right)$ in methanol. Compounds $\left[\mathrm{MoO}_{2}\left(\mathrm{HL}^{\mathrm{R}}\right)\left(\mathrm{H}_{2} \mathrm{O}\right)\right] \mathrm{Cl}$ $(\mathbf{1} \mathbf{a}-\mathbf{3 a})$ were obtained upon exposure of the corresponding mononuclear complexes 1-3 to moisture. Deprotonation of the mononuclear complexes 1-3 was performed by using $\mathrm{Et}_{3} \mathrm{~N}$ as a base (by the conventional solution based-method and by the mechanochemical approach) as well as by UV-light assisted reactions yielding $\left[\mathrm{MoO}_{2}\left(\mathrm{LIH}^{\mathrm{SIH}}\right)(\mathrm{MeOH})\right](4),\left[\mathrm{MoO}_{2}\left(\mathrm{~L}^{\mathrm{NIH}}\right)(\mathrm{MeOH})\right](\mathbf{5})$ and $\left[\mathrm{MoO}_{2}\left(\mathrm{~L}^{\mathrm{Et}}{ }^{\mathrm{NSIH}}\right)\right]_{n}(\mathbf{6})$, respectively. Crystal and molecular structures of all complexes were determined by the single crystal $\mathrm{X}$-ray diffraction method. The complexes were further characterized by elemental analysis, IR spectroscopy, TG analysis, one- and two-dimensional NMR spectroscopy and powder X-ray diffraction.
\end{abstract}

\section{Introduction}

The chemistry of hydrazones is continuing to be an interesting area of research because of their modularity, easiness of synthesis and stability towards hydrolysis. ${ }^{1}$ It is known that aroylhydrazones can exist in solution as configurational isomers (in $E$ or $Z$ forms) or in tautomeric forms $(=\mathrm{N}-\mathrm{NH}-(\mathrm{C}=\mathrm{O})-$ or $=\mathrm{N}-\mathrm{N}=(\mathrm{C}-\mathrm{OH})-)$ that occur in equilibrium. In most cases they have an acidic proton and their coordination to transition metals often leads to proton displacement. ${ }^{1}$ Depending on the protonaccepting ability, metal complexes with neutral $\left(\mathrm{H}_{2} \mathrm{~L}\right)$, singly$\left(\mathrm{HL}^{-}\right)$and doubly-deprotonated ligands $\left(\mathrm{L}^{2-}\right)$ can be obtained. ${ }^{2}$ In such a way different dimensionalities of the hydrogen-bonded networks can be formed. The protonation state of these ligands in metal complexes plays an important role since it offers finetuning of properties such as electrochemical, photophysical or catalytic. $^{3}$ Recent attention has been paid to the configurational

\footnotetext{
${ }^{a}$ University of Zagreb, Faculty of Science, Department of Chemistry, Horvatovac, 102a, 10000 Zagreb, Croatia.E-mail:visnja.vrdoljak@chem.pmf.hr; Fax: +385-1-4606341; Tel: +385-1-4606353

${ }^{b}$ INA-Industrija nafte d.d., Refining \& marketing business division, Product development department, Lovinčićeva bb, 10002 Zagreb, Croatia

$\dagger$ Electronic supplementary information (ESI) available: (1) XRPD patterns, (2) spectral data, (3) tables and (4) figures for compounds. CCDC 1062693-1062700. See DOI: $10.1039 / \mathrm{c} 5 n j 01567 \mathrm{~g}$
}

switching mechanism based on coordination-coupled deprotonation which explains the role of hydrazone deprotonation in activating the molecular switch. ${ }^{4}$

Isoniazid-related aroylhydrazones and their coordination compounds are of great interest owing to their biological activities $^{5}$ and their structural diversity. Thus, depending on the reaction conditions, $c i s-\left\{\mathrm{MoO}_{2}\right\}^{2+}$ structural units can form interesting supramolecular assemblies $\left[\mathrm{MoO}_{2}(\mathrm{~L})\right]_{x}(x=4,6$ or $n)$, where the nitrogen atom of the isonicotinyl moiety coordinates an additional neighboring metal atom. ${ }^{6-9}$ Otherwise, the sixth coordination site is occupied by the oxygen atom from the solvent D thus forming mononuclear complexes $\left[\mathrm{MoO}_{2}(\mathrm{~L}) \mathrm{D}\right]$. In these compounds, the hydrazone ligand is in the doublydeprotonated $\left(\mathrm{L}^{2-}\right)$ form. Surprisingly, chloride salts of charged dioxidomolybdenum(vi) complexes with tridentate ONO-donor ligands are very rare. Only two such structures have been published to date. ${ }^{10}$

A typical method employed in the preparation of some fully deprotonated metal complexes involves addition of a base during the complexation reaction, commonly in organic solvents. ${ }^{1}$ To the best of our knowledge, alternative methods towards deprotonation of cis-dioxidomolybdenum(vI) complexes (including grinding or UV irradiation as the method of activation) were not investigated. With these possibilities in mind, we set out to explore the influence of UV light on singly protonated 


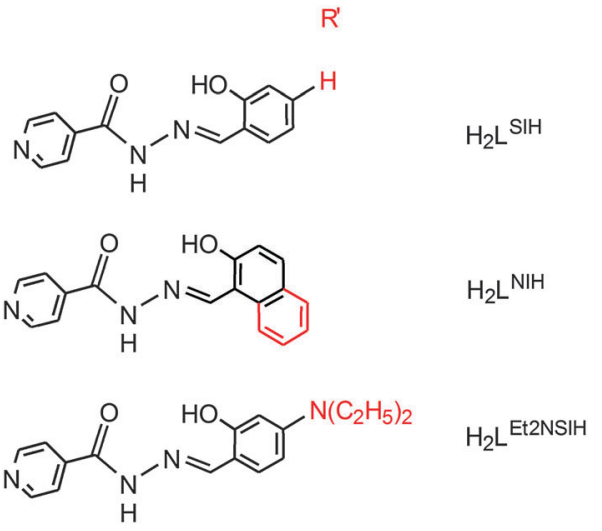

Scheme 1 The isoniazid-based hydrazones $\mathrm{H}_{2} \mathrm{~L}^{\mathrm{R}}$.

isonicotinoyl hydrazone complexes to see if deprotonation of the pyN- $\mathrm{H}^{+}$moiety could proceed without a photoinduced $E$-to- $Z$ configurational switch about the hydrazone double bond. Deprotonation has been investigated also by using $\mathrm{Et}_{3} \mathrm{~N}$ as a base (by a conventional solution-based method and a mechanochemical approach). To achieve this aim we have prepared and characterized dioxidomolybdenum(vI) complexes $\left[\mathrm{MoO}_{2}\left(\mathrm{HL}^{\mathrm{R}}\right)(\mathrm{MeOH})\right] \mathrm{Cl}$ (1-3) with three ligands, $\mathrm{H}_{2} \mathrm{~L}^{\mathrm{R}}$, salicylaldehyde isonicotinoylhydrazone $\left(\mathrm{H}_{2} \mathrm{~L}^{\mathrm{SIH}}\right)$, 2-hydroxy-naphthaldehyde isonicotinoylhydrazone $\left(\mathrm{H}_{2} \mathrm{~L}^{\mathrm{NIH}}\right)$, and $p$ - $\left(N, N^{\prime}\right.$-diethylamino)salicylaldehyde isonicotinoylhydrazone $\left(\mathrm{H}_{2} \mathrm{~L}^{\mathrm{Et} 2 \mathrm{NSIH}}\right)$, Scheme 1 . We were also interested to investigate the importance of nonbonding interactions in the structures as well as the ability of these complexes to form different hydrogen-bonded networks depending on the protonation state of the complexes.

\section{Results and discussion}

\section{Synthesis of dioxidomolybdenum(vi) complexes}

Synthesis of $\left[\mathrm{MoO}_{2}\left(\mathrm{HL}^{\mathrm{R}}\right)(\mathrm{MeOH})\right] \mathrm{Cl}$ was carried out in dry methanol using $\mathrm{MoO}_{2} \mathrm{Cl}_{2}$ and the corresponding aroylhydrazone $\mathrm{H}_{2} \mathrm{~L}^{\mathrm{R}}\left(\mathrm{R}=\mathrm{SIH}\right.$, NIH or $\left.\mathrm{Et}_{2} \mathrm{NSIH}\right)$, Scheme 2. In all of the investigated compounds formed after chelation, the ligands are found to be in the singly-deprotonated form $\left(\mathrm{HL}^{\mathrm{R}}\right)^{-}$coordinated to the cis- $\left\{\mathrm{MoO}_{2}\right\}^{2+}$ core via the ONO donor atoms. The cis$\left\{\mathrm{MoO}_{2}\right\}^{2+}$ core is additionally coordinated by a solvent molecule resulting in the formation of $\left[\mathrm{MoO}_{2}\left(\mathrm{HL}^{\mathrm{R}}\right)(\mathrm{MeOH})\right] \mathrm{Cl}$, where $\mathrm{R}=$ $\mathrm{SIH}$ (1), NIH (2) or $\mathrm{Et}_{2} \mathrm{NSIH}$ (3), respectively. If the reaction was not performed in dry methanol a mixture of the corresponding $\left[\mathrm{MoO}_{2}\left(\mathrm{HL}^{\mathrm{R}}\right)(\mathrm{MeOH})\right] \mathrm{Cl}$ and $\left[\mathrm{MoO}_{2}\left(\mathrm{HL}^{\mathrm{R}}\right)\left(\mathrm{H}_{2} \mathrm{O}\right)\right] \mathrm{Cl}$ complexes was obtained. All of the isolated compounds 1-3 are moisturesensitive crystalline solids (Fig. S1, see ESI $\dagger$ ). Exposure of samples 1-3 to water vapour resulted in crystalline products distinct from the starting compounds. In all cases they were identified to be $\left[\mathrm{MoO}_{2}\left(\mathrm{HL}^{\mathrm{R}}\right)\left(\mathrm{H}_{2} \mathrm{O}\right)\right] \mathrm{Cl}(\mathbf{1 a}-\mathbf{3 a})$ where the coordination sphere around the molybdenum atom is completed by coordination of a water molecule. Crystals of 1a suitable for single crystal $\mathrm{X}$-ray diffraction were obtained from wet methanol, whereas those of $2 \mathbf{a}$ and $3 \mathbf{a} \cdot \mathbf{H}_{2} \mathbf{O}$ were obtained from wet acetonitrile.

\section{Deprotonation reactions}

Treatment of $\left[\mathrm{MoO}_{2}\left(\mathrm{HL}^{\mathrm{R}}\right)(\mathrm{MeOH})\right] \mathrm{Cl}(\mathbf{1}$ and 2) with a stoichiometric amount of $\mathrm{Et}_{3} \mathrm{~N}$ in methanol (method $\left.\mathrm{A}\right)$ at room temperature afforded $\mathrm{Et}_{3} \mathrm{NCl}$ and the mononuclear complexes $\left[\mathrm{MoO}_{2}\left(\mathrm{~L}^{\mathrm{SIH}}\right)(\mathrm{MeOH})\right](4)$ and $\left[\mathrm{MoO}_{2}\left(\mathrm{~L}^{\mathrm{NIH}}\right)(\mathrm{MeOH})\right]$ (5), respectively. The reaction of 3 with $\mathrm{Et}_{3} \mathrm{~N}$ proceeds differently and the coordination polymer $\left[\mathrm{MoO}_{2}\left(\mathrm{~L}^{\mathrm{Et}_{2} \mathrm{NSIH}}\right)\right]_{n}(\mathbf{6})$ was obtained without
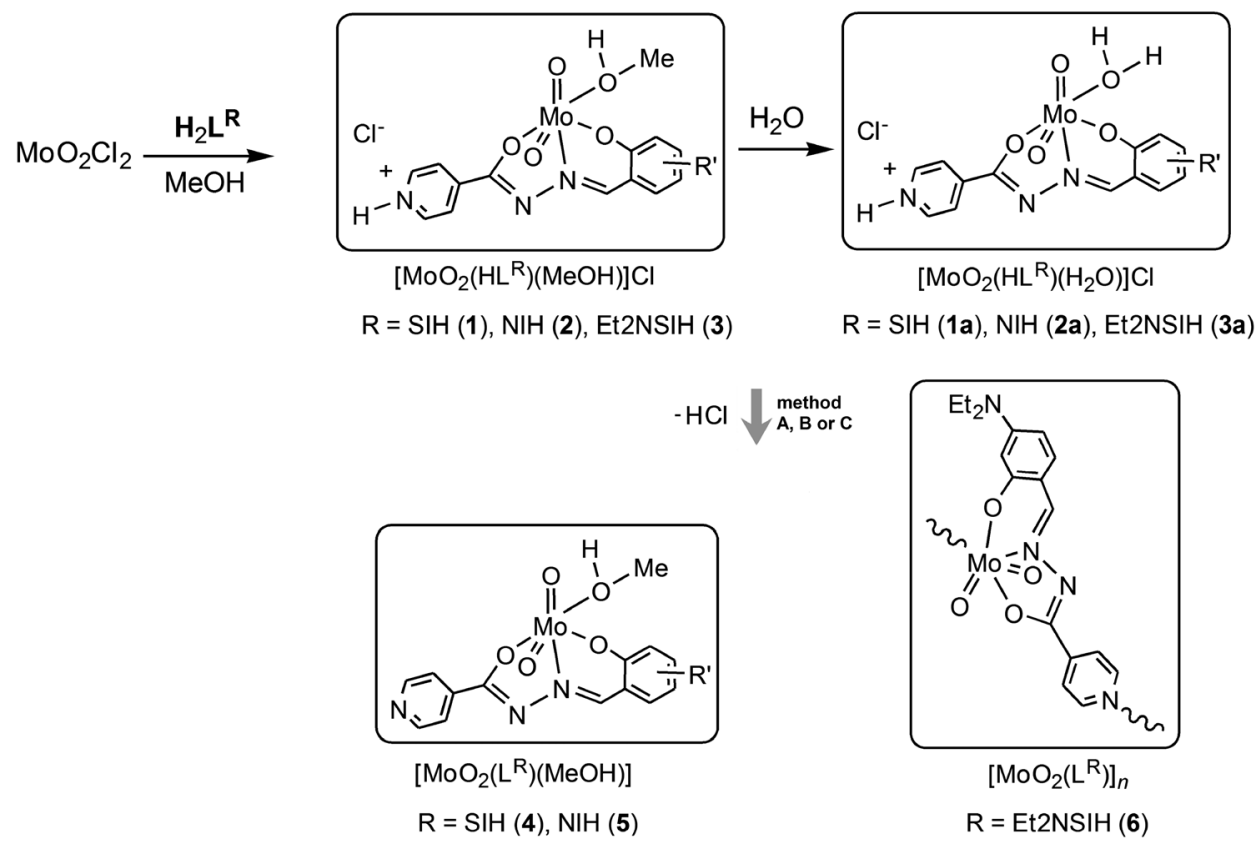

Scheme 2 Synthesis of the complexes $\left[\mathrm{MoO}_{2}\left(\mathrm{HL} \mathrm{L}^{\mathrm{R}}\right)(\mathrm{MeOH})\right] \mathrm{Cl}(\mathbf{1 - 3})$ and $\left[\mathrm{MoO}_{2}\left(\mathrm{HL}^{\mathrm{R}}\right)\left(\mathrm{H}_{2} \mathrm{O}\right)\right] \mathrm{Cl}(\mathbf{1} \mathbf{a}-\mathbf{3 a})$ with singly-deprotonated ligands and synthesis of the doubly-deprotonated complexes $\left[\mathrm{MoO}_{2}\left(\mathrm{~L}^{\mathrm{R}}\right)(\mathrm{MeOH})\right](\mathbf{4}$ and $\mathbf{5})$ and $\left[\mathrm{MoO}_{2}\left(\mathrm{~L}^{\mathrm{Et}} \mathrm{NSIH}^{\mathrm{N}}\right)\right]_{n}(\mathbf{6})$ by using Et ${ }_{3} \mathrm{~N}$ as a base (by the conventional solution-based method (A), by the mechanochemical approach (B)), and by the UV-light assisted method (C). 
isolation of the corresponding mononuclear complex. It is expected that the deprotonation reaction leads to the formation of a labile intermediate complex with the coordinated methanol molecule, which is then displaced by the isonicotinoyl part of the neighbouring molecule. Compounds 4-6 were synthesised more easily by liquid-assisted grinding (LAG) of the complexes 1-3 and $\mathrm{Et}_{3} \mathrm{~N}$ in the presence of a small amount of methanol (method B). Triethylammonium chloride impurities can be removed by rinsing the products with water affording 4-6 in a pure, chloride-free form. Compounds 4-6 can be prepared alternatively by photoassisted deprotonation of the corresponding complexes 1-3 (method C). To achieve deprotonation, mononuclear complexes were exposed to $\mathrm{UV}$ radiation $(254 \mathrm{~nm})$ in dry methanol. Absence of chloride in the prepared compounds was proven by a negative test reaction with aqueous $\mathrm{AgNO}_{3}$.

In complexes 4-6, the ligands are coordinated tridentately in the doubly-deprotonated form $\left(\mathrm{L}^{\mathrm{R}}\right)^{2-}$ to the molybdenum centre. The remaining sixth coordination site is occupied by the oxygen atom of the solvent methanol molecule (in 4 and 5) or by the nitrogen atom of the bridging isonicotinyl moiety of the neighboring complex (in 6). This suggests that the obtained complexes are inert towards further photoisomerization. To the best of our knowledge, deprotonation of cis-dioxidomolybdenum(vi) complexes leading to formation of the mononuclear complexes or polynuclear assemblies through a UV-light assisted reaction or by mechanochemical synthesis has not been reported so far.

Crystal and molecular structures of 5 and $\mathbf{6}$ were determined by the single crystal X-ray diffraction method. The crystals of 4 are identical to those known from the literature. ${ }^{11}$ The products obtained by methods A, B and C (Scheme 2) were examined also by PXRD, Fig. 1 (Fig. S2 and S3, see ESI $\dagger$ ). Although grinding of 1-5 during sample preparation for PXRD experiments resulted in a partial release of the coordinated solvent molecule

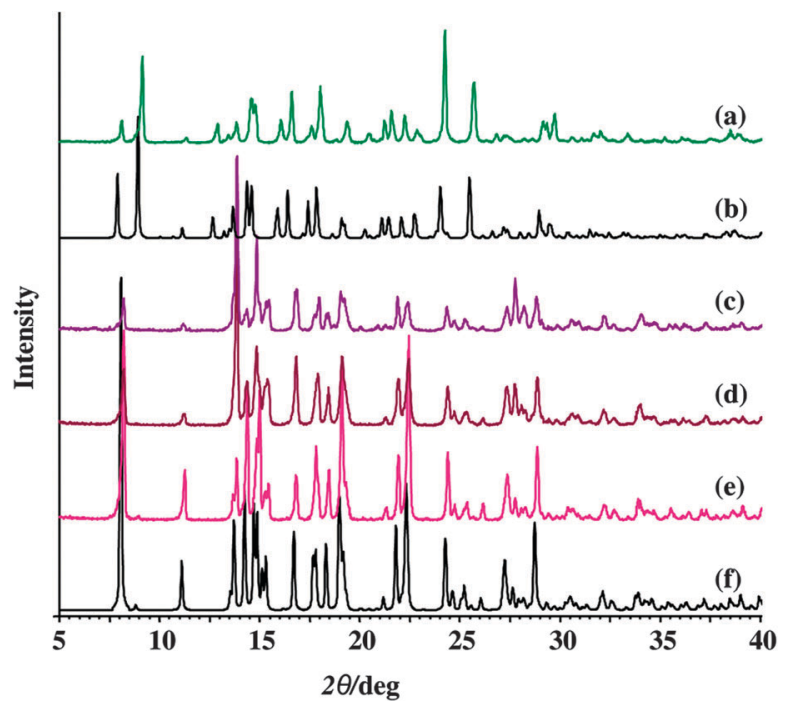

Fig. 1 PXRD patterns of $\mathbf{3}$ ( $a$ and b); 6 (c-f). The colored lines indicate patterns obtained by powder diffraction, $\mathrm{Cu} K \alpha$ radiation ((c) sample obtained by method A, (d) sample obtained by method B and (e) sample obtained by method C)), while the black lines indicate patterns calculated from the X-ray single-crystal structures of the corresponding compounds. (about 1\% according to TG measurements) this change was not significant and PXRD patterns could be used for comparison with those calculated from the structures obtained by the single crystal X-ray diffraction method.

\section{Thermogravimetric analyses}

Crystals of all samples were used for TG analysis without grinding in the atmosphere of pure oxygen (at a heating rate of $\left.5{ }^{\circ} \mathrm{C} \mathrm{min}{ }^{-1}\right)$. TG study of the $\left[\mathrm{MoO}_{2}\left(\mathrm{HL}^{\mathrm{R}}\right)(\mathrm{MeOH})\right] \mathrm{Cl}$ complexes revealed that three main processes occurred: desolvation, loss of a $\mathrm{HCl}$ molecule and decomposition. In the case of the mononuclear complexes 1 and 2 the loss of $\mathrm{MeOH}$ and $\mathrm{HCl}$ molecules proceeded in a stepwise fashion: in the range $174-204{ }^{\circ} \mathrm{C}$ and $223-276{ }^{\circ} \mathrm{C}$ for $1,113-151{ }^{\circ} \mathrm{C}$ and $172-206{ }^{\circ} \mathrm{C}$ for 2 . However, desolvation of $\mathbf{3}$ was accompanied by the release of a $\mathrm{HCl}$ molecule without formation of a stable intermediate product (in the range 120-194 ${ }^{\circ} \mathrm{C}$ ). Upon further heating, the non-solvated products decomposed. During decomposition a significant mass loss occurred in the range $288-507{ }^{\circ} \mathrm{C}$ (1); 317-546 ${ }^{\circ} \mathrm{C}(2)$; $251-$ $503{ }^{\circ} \mathrm{C}(3)$ and afforded $\mathrm{MoO}_{3}$ as the final residue.

The thermal analysis data for the mononuclear complexes $\left[\mathrm{MO}_{2}\left(\mathrm{~L}^{\mathrm{R}}\right)\left(\mathrm{H}_{2} \mathrm{O}\right)\right] \mathrm{Cl}$ showed a similar thermal behaviour. The mass loss for complexes $1 \mathbf{1 a}, \mathbf{2 a}$ and $\mathbf{3} \mathbf{a} \cdot \mathbf{H}_{2} \mathbf{O}$ corresponded to the loss of $\mathrm{H}_{2} \mathrm{O}$ and $\mathrm{HCl}$ molecules (in the range $120-142{ }^{\circ} \mathrm{C}$ and 208-249 ${ }^{\circ} \mathrm{C}$ for $1 \mathrm{a}, 50-105{ }^{\circ} \mathrm{C}$ and $128-246{ }^{\circ} \mathrm{C}$ for $2 \mathrm{a}$, and 59-96 ${ }^{\circ} \mathrm{C}$ and $201-250{ }^{\circ} \mathrm{C}$ for $\mathbf{3 a} \cdot \mathbf{H}_{2} \mathbf{O}$ ), whereas decomposition of these complexes occurred in the range $323-512{ }^{\circ} \mathrm{C}$ for $\mathbf{1 a}$, $278-494{ }^{\circ} \mathrm{C}$ for $\mathbf{1 b}$ and $286-501{ }^{\circ} \mathrm{C}$ for $\mathbf{3 a} \cdot \mathbf{H}_{2} \mathbf{O}$. Complexes 4 and 5 exhibited a first mass loss (in the range $158-181{ }^{\circ} \mathrm{C}$ for 4 , and 161-182 ${ }^{\circ} \mathrm{C}$ for 5) corresponding to the release of the coordinated methanol molecule, whereas decomposition of the complexes occurred in the range $349-477{ }^{\circ} \mathrm{C}$ for 4 , and $304-500{ }^{\circ} \mathrm{C}$ for 5. For the polynuclear complex, the mass loss was observed only in the temperature range $254-474{ }^{\circ} \mathrm{C}(6)$.

\section{Spectroscopic characterisation}

All complexes were characterized also by IR spectral data. Compounds were identified by the appearance of the stretching frequencies characteristic for $\nu_{\text {asym }}\left(\mathrm{MoO}_{2}\right)$ (found at about 945-935 $\mathrm{cm}^{-1}$ ) and antisymmetric combination of $\mathrm{Mo}=\mathrm{O}$ and Mo-O $\mathrm{O}_{\mathrm{EtOH}}$ stretchings (found at $c a .910 \mathrm{~cm}^{-1}$ for 1-5). The corresponding symmetric stretching bands $\nu_{\text {sym }}\left(\mathrm{MoO}_{2}\right)$ having significantly lower intensities appear in the same region but they either overlap with the asymmetric ones or appear as shoulders. ${ }^{12}$ The bands found in the IR spectra of $\mathrm{H}_{2} \mathrm{~L}^{\mathrm{R}}$, characteristic for the $\mathrm{C}=\mathrm{O}$ vibration at $c a .1680 \mathrm{~cm}^{-1}$ and $\mathrm{N}-\mathrm{H}$ vibration (at $3180 \mathrm{~cm}^{-1}\left(\mathrm{H}_{2} \mathrm{~L}^{\mathrm{SIH}}\right), 3223 \mathrm{~cm}^{-1}\left(\mathrm{H}_{2} \mathrm{~L}^{\mathrm{NIH}}\right)$, $\left.3215 \mathrm{~cm}^{-1}\left(\mathrm{H}_{2} \mathrm{~L}^{\mathrm{Et}_{2} \mathrm{NSIH}}\right)\right)$, are absent in the IR spectra of $1-3$, suggesting the hydrazone tautomerism $(=\mathrm{N}-\mathrm{NH}-(\mathrm{C}=\mathrm{O})-\rightarrow$ $=\mathrm{N}-\mathrm{N}=(\mathrm{C}-\mathrm{OH})-)$, deprotonation and coordination through the oxygen atom. This is also supported by the presence of a new band at $c a .1330 \mathrm{~cm}^{-1}$ assigned to the $\mathrm{C}-\mathrm{O}$ group of the hydrazone moiety. ${ }^{13}$ The bands typical for $\mathrm{C}=\mathrm{N}_{\text {imine }}$ and $\mathrm{C}-\mathrm{O}_{\text {phenolic }}$ appear at $c a .1610 \mathrm{~cm}^{-1}$ and $1550 \mathrm{~cm}^{-1}$, respectively. A band at around $1050 \mathrm{~cm}^{-1}$ seen in the IR spectra of 1-5 is assigned to the $\mathrm{C}-\mathrm{O}$ stretching vibration of the coordinated 

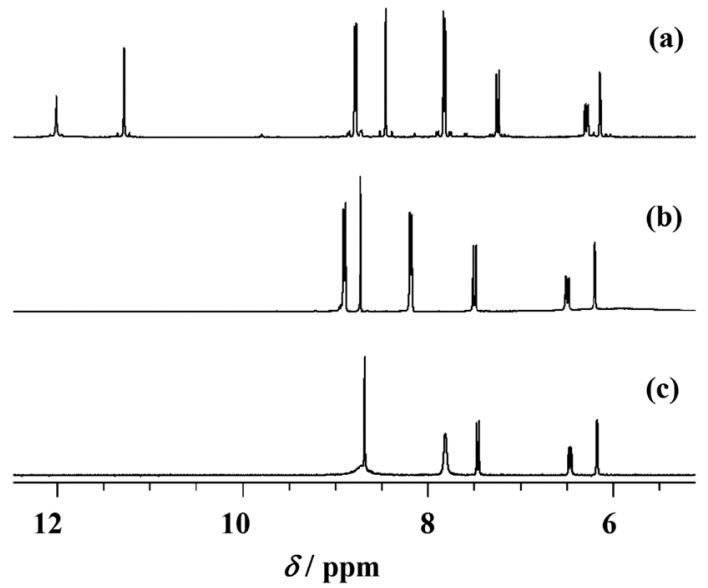

Fig. $2{ }^{1} \mathrm{H}$ NMR spectra of $\mathrm{H}_{2} \mathrm{~L}^{\mathrm{Et} 2 \mathrm{NSIH}}$ (a), 3 (b) and 6 (c) in DMSO- $d_{6}$.

MeOH molecule. ${ }^{14}$ This band is absent in the spectra of 1a-3a and 6. Formation of the Mo- $\mathrm{N}_{\text {isonicotinyl }}$ bond is additionally supported by the presence of a band at $907 \mathrm{~cm}^{-1}$ assigned to

(a)

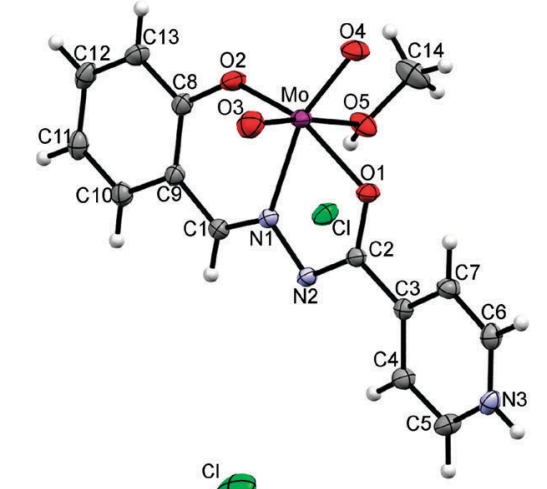

(b)

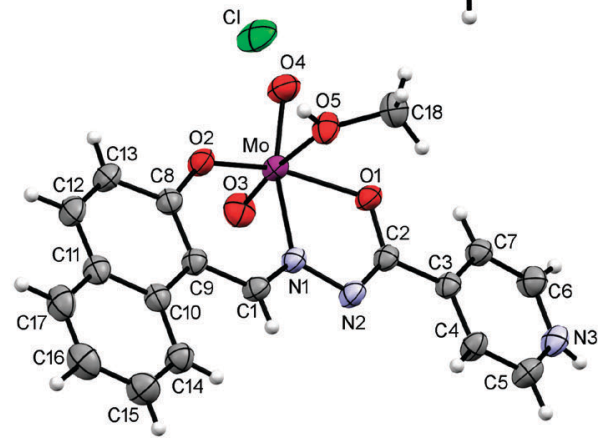

(c)

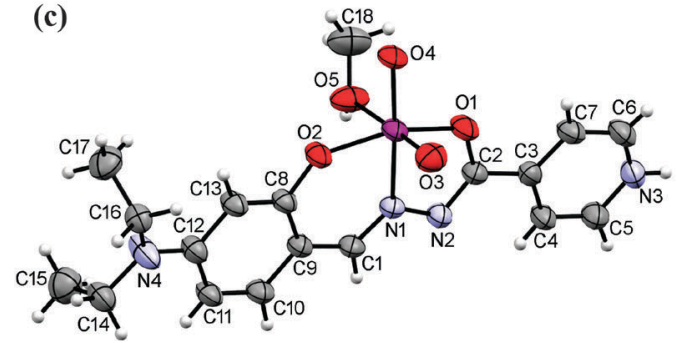

Fig. 3 ORTEP drawings of the ions in $\mathbf{1}$ (a), $\mathbf{2}$ (b) and $\mathbf{3}$ (c) with the atomlabeling scheme (displacement ellipsoids of non-hydrogen atoms are drawn at the $50 \%$ probability level). $\nu_{\text {asym }}\left(\mathrm{O}=\mathrm{Mo}-\mathrm{N}_{\text {isonicotinyl }}\right)$ and absence of a broad band at $\approx 850 \mathrm{~cm}^{-1}$ characteristic for an intermolecular $\mathrm{Mo}=\mathrm{O} \cdots \mathrm{Mo}$ interaction. ${ }^{15}$

The NMR analysis has confirmed chemical structures of all compounds in solution. The proton and carbon chemical shifts (Tables S1-S3, see ESI $\dagger$ ) were assigned by using one $\left({ }^{1} \mathrm{H}\right.$ and $\mathrm{APT}$ ) and two-dimensional NMR experiments (COSY, HSQC and HMBC). The proton spectra of the ligand molecules displayed signals resonating at $\sim 11 \mathrm{ppm}$ and $\sim 12 \mathrm{ppm}$ which were assigned to $\mathrm{OH}$ and $\mathrm{N}=\mathrm{NH}$ protons, respectively (Fig. 2). The signals were somewhat broadened indicating their involvement in hydrogen bonding interactions.

In the compounds $\left[\mathrm{MoO}_{2}\left(\mathrm{HL}^{\mathrm{R}}\right)(\mathrm{MeOH})\right] \mathrm{Cl}(\mathbf{1}-\mathbf{3})$ these signals disappeared indicating their deprotonation upon coordination of the ligand to molybdenum. Simultaneously, the pyridine nitrogen became protonated which is supported by the appearance of new signals at 3.17-4.66 ppm (Tables S1-S3, see ESI $\dagger$ ). As a consequence of these reactions the neighboring atoms were also affected resulting in changes in their chemical shifts. In compounds $\left[\mathrm{MoO}_{2}\left(\mathrm{~L}^{\mathrm{SIH}}\right)(\mathrm{MeOH})\right](4),\left[\mathrm{MoO}_{2}\left(\mathrm{~L}^{\mathrm{NIH}}\right)(\mathrm{MeOH})\right]$ (5) and $\left[\mathrm{MoO}_{2}\left(\mathrm{~L}^{\mathrm{Et}_{2} \mathrm{NSIH}}\right)\right]_{n}(\mathbf{6})$ the signal belonging to the pyN- $\mathrm{H}^{+}$ moiety is absent indicating full deprotonation and formation of new molybdenum complexes. That was confirmed by up- and

(a)

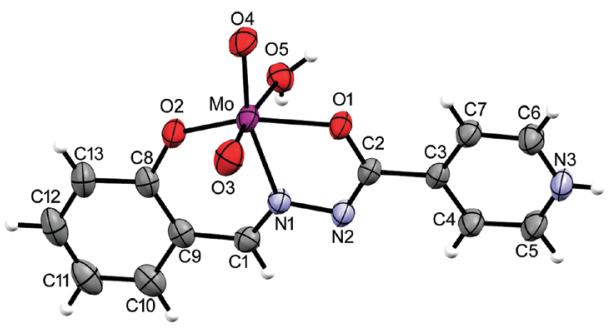

(b)

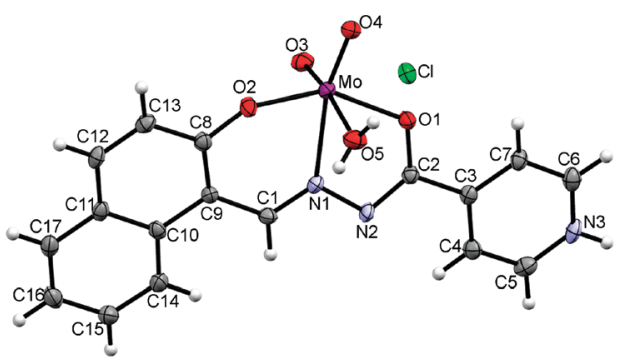

(c)

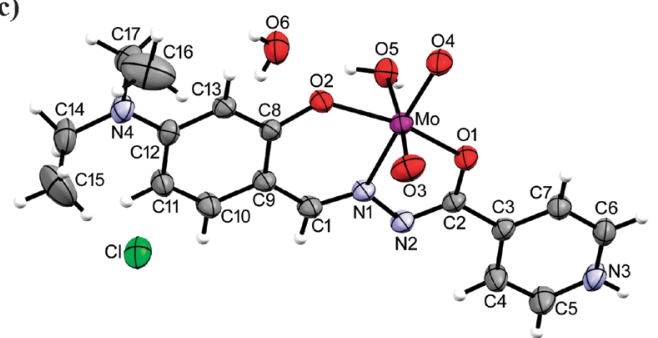

Fig. 4 ORTEP drawings of the ions in $\mathbf{1 a}(\mathrm{a}), \mathbf{2 a}(\mathrm{b})$ and $\mathbf{3 a} \cdot \mathrm{H}_{2} \mathrm{O}$ (c) with the atom-labeling scheme (displacement ellipsoids of non-hydrogen atoms are drawn at the $50 \%$ probability level). 
down-field shifts observed for neighboring hydrogen and carbon atoms (as can be noticed in Fig. 2), as a result of electron redistribution upon complexation. The largest effects were detected in compound 6 for carbons C-5 and C-7,9 amounting to $5.42 \mathrm{ppm}$ and -5.15 ppm, respectively. The atoms C-6,10, C-4 and C-1 were also affected but to a smaller extent. These findings are in accordance with the crystal structures obtained for these compounds.

\section{Crystallographic studies}

The ligand coordinates the metal centre of the $\mathrm{cis}-\mathrm{MoO}_{2}{ }^{2+}$ core tridentately via the phenolic-oxygen, azomethine-nitrogen and isonicotinic-oxygen forming five and six membered chelate rings in all complexes. The sixth coordination molybdenum

(a)

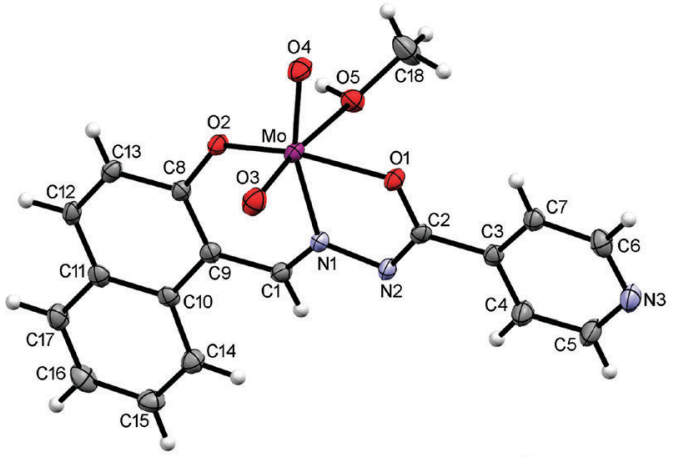

(b)

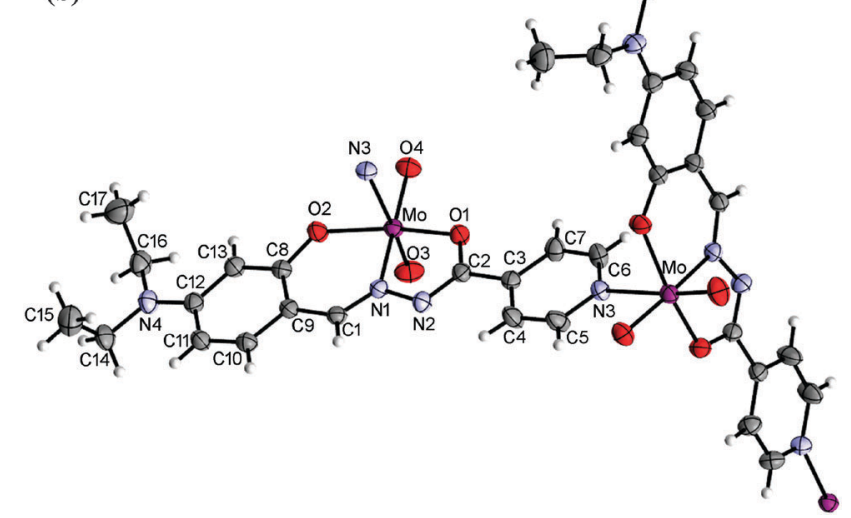

Fig. 5 ORTEP drawings of the molecules of 5 (a) and $\mathbf{6}(\mathrm{b})$ with the atomlabeling scheme (displacement ellipsoids of non-hydrogen atoms are drawn at the $50 \%$ probability (evel). site is occupied by the oxygen atom from the solvent (methanol or water) thus forming mononuclear complexes 1-3 (Fig. 3), 1a, 2a, 3a. $\mathbf{H}_{2} \mathbf{O}$ (Fig. 4) and 5 (Fig. 5(a)). An exception is the coordination polymer $\mathbf{6}$ (Fig. 5(b)) where the coordination sphere is completed by the nitrogen atom of the isonicotinyl moiety of a neighboring molybdenum complex. This moiety acts as a linker between the molybdenum centers and enables formation of a larger structural assembly, a 1D zig-zag coordination polymer.

In all reported complexes the coordination sphere of molybdenum is a distorted octahedron (Tables 1 and 2). The smallest cis-angle at the Mo atom is that of O1-Mo-N1 being in the range from $71.63(5)^{\circ}$ in 1 to $72.42(8)^{\circ}$ in $2 \mathrm{a}$, while the largest one involves the oxo-oxygen atoms O3-Mo-O4 being in the range from $105.21(7)^{\circ}$ in 1 to $105.99(9)^{\circ}$ in 5 .

The distance from the molybdenum atom to the $\mathrm{O}$ atom from the solvent molecule $\left(\mathbf{1}-\mathbf{3}, \mathbf{5}, \mathbf{1 a}, \mathbf{2 a}, \mathbf{3} \mathbf{a} \cdot \mathbf{H}_{\mathbf{2}} \mathbf{O}\right)$ or the $\mathrm{N}$ atom of the isonicotinyl moiety (6) represents the largest bond length within the octahedron. The ligand is singly deprotonated in compounds 1-3 and 1a, 2a and $\mathbf{3 a} \cdot \mathbf{H}_{2} \mathbf{O}$ which are all chloride salts, whereas in compounds $\mathbf{5}$ and $\mathbf{6}$ it is doubly deprotonated resulting in neutral complexes. The ligands are not planar, the smallest and largest deviation from planarity is that between the isonicotinyl and phenyl/naphthaldehyde moieties in compounds $6\left(3.85(12)^{\circ}\right)$ and 2 , respectively $\left(8.47(9)^{\circ}\right.$, Table S4, see ESI $\dagger$ ), and between the five- and six-membered chelate rings in compounds $3\left(5.20(10)^{\circ}\right)$ and $5\left(8.32(9)^{\circ}\right.$, Table S4, ESI $\dagger)$. The $\mathrm{C} 1-\mathrm{N} 1$ bond in the complexes is not significantly different from that in the free ligands. ${ }^{16,17} \mathrm{How}^{-}$ ever, the bond length $\mathrm{N} 2-\mathrm{C} 2$ is shortened, whereas that of $\mathrm{N} 1-\mathrm{N} 2$ is lengthened in the complexes in comparison to the free ligands $\mathrm{H}_{2} \mathrm{~L}^{\mathrm{NIH}}\left(1.357(3) \AA\right.$ and $1.370(2) \AA$, respectively) ${ }^{16}$ and $\mathrm{H}_{2} \mathrm{~L}^{\mathrm{SIH}}\left(1.3558(17) \AA\right.$ and $1.3699(15) \AA$, respectively) ${ }^{17}$ due to the electron delocalization.

Complexes 1, 2 and 3 (Fig. 6) have two hydrogen bond donors, the methanol hydroxyl group and the protonated nitrogen atom of the isonicotinyl moiety. They are both involved in hydrogen bonding to the chloride ion (Table S5, see ESI $\dagger$ ). Hydrogen bonds of the type $\mathrm{N}-\mathrm{H} \cdots \mathrm{Cl}$ are in the range from 2.988(3) $\AA$ in 3 to 3.0199(16) $\AA$ in 1, and are shorter than those involving the hydroxyl group, $\mathrm{O}-\mathrm{H} \cdots \mathrm{Cl}$ which are from 3.057(3) $\AA$ in 3 to 3.0936(16) $\AA$ in 1 .

The longer hydrogen bonds are formed in $\mathbf{1}$ and $\mathbf{2}$ where the hydrogen bonds connect the complex molecules into infinite one-dimensional chains $\left(\mathrm{C}_{2}^{1}(11)\right)$ parallel to the $c$-axis, in contrast

Table 1 Selected bond lengths ( $\AA$ ) for compounds $1,2,3,5,6,1 a, 2 a$ and $3 a \cdot H_{2} \mathrm{O}$

\begin{tabular}{|c|c|c|c|c|c|c|c|c|}
\hline & 1 & 2 & 3 & 5 & 6 & $1 a$ & $2 a$ & $3 \mathbf{a} \cdot \mathrm{H}_{2} \mathrm{O}$ \\
\hline Mo-O1 & $2.0046(13)$ & $1.9976(15)$ & $2.021(2)$ & $2.0083(17)$ & $2.0218(17)$ & $2.0141(18)$ & $2.0156(19)$ & $2.0309(12)$ \\
\hline Mo-O2 & $1.9221(14)$ & $1.9275(16)$ & $1.911(2)$ & $1.9439(18)$ & 1.9399(19) & $1.9183(17)$ & $1.9539(17)$ & $1.9316(11)$ \\
\hline Mo-O3 & $1.6965(15)$ & $1.6847(16)$ & $1.685(2)$ & $1.6951(18)$ & $1.689(2)$ & $1.687(2)$ & $1.746(2)$ & $1.6949(17)$ \\
\hline Mo-O4 & $1.7039(13)$ & $1.6921(17)$ & $1.709(2)$ & $1.7044(18)$ & $1.7069(19)$ & $1.6969(18)$ & $1.7026(18)$ & $1.7134(13)$ \\
\hline Mo-O5 & $2.3363(15)$ & $2.3828(16)$ & $2.400(3)$ & $2.3538(18)$ & - & $2.381(2)$ & $2.288(2)$ & $2.3503(17)$ \\
\hline Mo-N1 & $2.2485(15)$ & $2.2399(19)$ & $2.213(2)$ & $2.228(2)$ & $2.211(2)$ & $2.2431(19)$ & $2.232(3)$ & $2.2224(13)$ \\
\hline Mo-N3 & - & - & - & - & $2.531(2)$ & - & - & - \\
\hline C1-N1 & $1.291(2)$ & $1.297(3)$ & $1.303(4)$ & $1.290(3)$ & $1.298(3)$ & $1.288(3)$ & $1.293(4)$ & $1.297(2)$ \\
\hline $\mathrm{N} 1-\mathrm{N} 2$ & $1.405(2)$ & $1.397(3)$ & $1.388(3)$ & $1.398(3)$ & $1.395(3)$ & $1.395(3)$ & $1.396(3)$ & $1.3955(19)$ \\
\hline $\mathrm{N} 2-\mathrm{C} 2$ & $1.293(2)$ & $1.289(3)$ & $1.297(4)$ & $1.294(3)$ & $1.289(3)$ & $1.292(3)$ & $1.294(4)$ & $1.294(2)$ \\
\hline
\end{tabular}


Table 2 Selected angles $\left({ }^{\circ}\right)$ for compounds $1,2,3,5,6,1 \mathrm{a}, 2 \mathrm{a}$ and $3 \mathrm{a} \cdot \mathrm{H}_{2} \mathrm{O}$

\begin{tabular}{|c|c|c|c|c|c|c|c|c|}
\hline & 1 & 2 & 3 & 5 & 6 & $1 \mathbf{a}$ & $2 a$ & $3 \mathbf{a} \cdot \mathrm{H}_{2} \mathrm{O}$ \\
\hline $\mathrm{O} 1-\mathrm{Mo}-\mathrm{O} 3$ & $96.27(6)$ & $97.39(8)$ & $94.46(9)$ & $99.39(8)$ & $98.67(9)$ & $97.07(9)$ & $97.77(8)$ & $97.68(7)$ \\
\hline $\mathrm{O} 1-\mathrm{Mo}-\mathrm{O} 4$ & $95.91(6)$ & $97.79(7)$ & $95.31(9)$ & $96.56(8)$ & $95.90(8)$ & $95.92(8)$ & $97.96(8)$ & $94.97(6)$ \\
\hline O1-Mo-N1 & $71.63(5)$ & $71.78(6)$ & $71.85(8)$ & $72.41(7)$ & 72.15(7) & $71.87(7)$ & $72.42(8)$ & $71.76(5)$ \\
\hline O1-Mo-N3 & - & - & - & - & $81.34(7)$ & - & - & - \\
\hline $\mathrm{O} 2-\mathrm{Mo}-\mathrm{O} 3$ & $97.82(7)$ & 99.55(8) & $100.61(10)$ & 99.42(8) & $98.54(9)$ & 99.65(9) & $97.45(8)$ & $99.37(7)$ \\
\hline $\mathrm{O} 2-\mathrm{Mo}-\mathrm{N} 1$ & $81.90(5)$ & $80.67(7)$ & $81.66(8)$ & $79.88(7)$ & $81.58(8)$ & $80.78(7)$ & 79.71(8) & $82.52(5)$ \\
\hline $\mathrm{O} 2-\mathrm{Mo}-\mathrm{N} 3$ & - & - & - & - & $79.10(7)$ & - & - & - \\
\hline $\mathrm{O} 3-\mathrm{Mo}-\mathrm{O} 4$ & $105.21(7)$ & $105.94(8)$ & $105.34(10)$ & 105.99(9) & 105.35(9) & 105.92(10) & 105.61(9) & $105.28(8)$ \\
\hline O3-Mo-O5 & $172.16(6)$ & $169.25(8)$ & $173.27(10)$ & $170.63(8)$ & - & $171.20(8)$ & $171.71(9)$ & $171.68(6)$ \\
\hline O3-Mo-N1 & $97.70(6)$ & $93.48(8)$ & 100.02(9) & $95.07(8)$ & $95.10(9)$ & $96.17(9)$ & $93.45(8)$ & $93.96(6)$ \\
\hline O3-Mo-N3 & - & & & - & $174.27(8)$ & - & - & - \\
\hline
\end{tabular}

to 3 which is built up of centrosymmetrical dimers $\left(R_{4}^{2}(22)\right)$. Therefore, in these three complexes the typical hydrogen bonding connection is $\mathrm{N}-\mathrm{H} \cdots \mathrm{Cl} \cdots \mathrm{H}-\mathrm{O}$, which is either bent (1 and 3) or linear (2). It seems that the linear connection is more favorable for a shorter distance between the $\pi$ systems (Fig. 6).

In 1 there are $\pi \cdots \pi$ interactions $\mathrm{Cg} 3 \cdots \operatorname{Cg} 4[x, y, 1+z]$ of $3.6597(11) \AA$ and $\mathrm{Cg} 3 \cdots \mathrm{Cg} 4[1+x, y, 1+z]$ of 3.8484(11) between the isonicotinyl $(\mathrm{Cg} 3$ is the centroid of the ring $\mathrm{N} 3$, $\mathrm{C} 3-\mathrm{C} 7)$ and the phenyl moieties ( $\mathrm{Cg} 4$ is the centroid of the
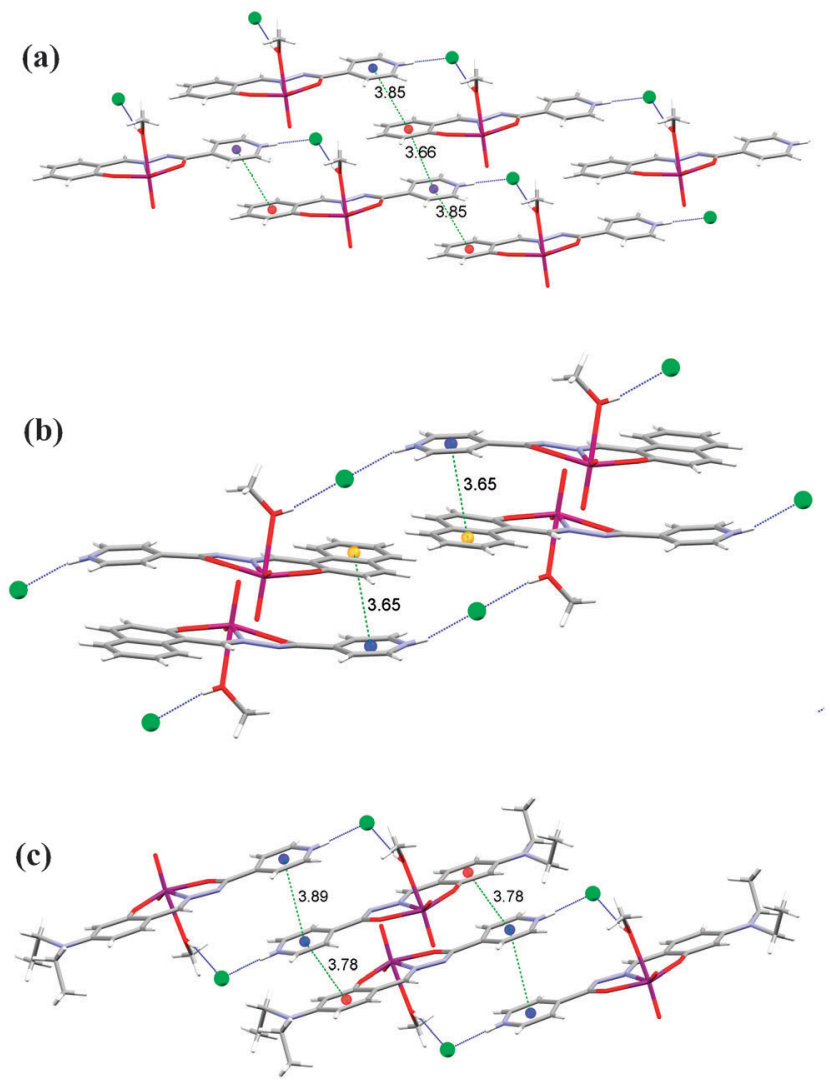

Fig. 6 Nonbonding interactions connecting the ions into supramolecular motifs in $\mathbf{1}$ (a), $\mathbf{2}$ (b) and $\mathbf{3}$ (c). Hydrogen bonds are shown by blue dotted lines. The distance between centroids (green dashed lines) is in $\AA$. ring C8-C13) (Fig. 6(a) and Table S6 see ESI $\dagger$ ). This centroid labeling is valid for all complexes. In 2 the chains are held together by $\pi \cdots \pi$ interactions between the isonicotinyl and the naphthaldehyde moieties, Cg3 $\cdots \operatorname{Cg} 4[2-x, 1-y, z]$ of $3.7770(14) \AA$ and $\mathrm{Cg} 3 \cdots \mathrm{Cg} 5[2-x, 1-y, z]$ of $3.6530(15) \AA$. $\mathrm{Cg} 5$ is the centroid of the outer phenyl ring of the naphthaldehyde moiety (C10, C11, C14-C17), which forms a shorter contact and is shown in Fig. 6(b) (Table S6, ESI $\dagger$ ). Complex 3 has the shortest hydrogen bonds among complexes 1-3 but the weakest $\pi \cdots \pi$ interactions due to the bulky diethylamino substituent on the salicylaldehyde moiety. These contacts amount to $\mathrm{Cg} 3 \cdots \mathrm{Cg} 4[1-x$, $-y, 1-z]$ of $3.7879(19) \AA$ and $\mathrm{Cg} 3 \cdots \mathrm{Cg} 3[1-x,-y,-z]$ of 3.8898(18) ^ (Fig. 6(c) and Table S6, ESI $\dagger$ ).

Complexes 1a, $\mathbf{2 a}$ and $\mathbf{3} \mathbf{a} \cdot \mathbf{H}_{2} \mathbf{O}$ (Fig. 7) have a water molecule coordinating the molybdenum atom and so there is one more hydrogen atom donor than in 1-3 thus forming a more extensive hydrogen bonding network. Indeed, both hydrogen atoms are involved as donors, in $\mathbf{1} \mathbf{a}$ and $\mathbf{2 a}$ toward chloride ions, while in $\mathbf{3 a} \cdot \mathbf{H}_{2} \mathbf{O}$ one is toward a chloride ion and the other toward the solvent water molecule. The presence of the solvent water molecules increases the number of hydrogen bonds that are found in the structure $3 \mathbf{a} \cdot \mathbf{H}_{2} \mathbf{O}$. The chloride ion is an acceptor of three (1a and $\left.\mathbf{3} \mathbf{a} \cdot \mathbf{H}_{2} \mathbf{O}\right)$ or four (2a) hydrogen bonds.

The $\mathrm{O}-\mathrm{H} \cdots \mathrm{Cl}$ bonds are in the range from 3.044(3) $\AA$ in $2 \mathrm{a}$ to $3.1729(18) \AA$ in $\mathbf{3} \mathbf{a} \cdot \mathbf{H}_{2} \mathbf{O}$, similarly as in $\mathbf{1 - 3}$. Hydrogen bonds of the type $\mathrm{N}-\mathrm{H} \cdots \mathrm{Cl}$ are longer than in 1-3 and range from 3.053(3) $\AA$ in 1a to 3.394(2) A in 2a. The supramolecular motifs that are formed are layers parallel to (100) made up of interconnected rings $\mathrm{R}_{4}^{2}(22)$ in 1a (Fig. 7(a)), a three-dimensional network in 2a (Fig. 7(b)), and double-layers parallel to (100) in 3a. $\mathbf{H}_{2} \mathbf{O}$ (Fig. 7(c)). Inside the double layer is the hydrophilic part while the bulky diethylamino substituents on the salicylaldehyde moiety extend into the hydrophobic part. $\pi \cdots \pi$ interactions are present only in $2 \mathrm{a} \operatorname{Cg} 5 \cdots \mathrm{Cg} 3[1-x, 1-y, 2-z]$ of $3.5529(16) \AA$ and $\mathrm{Cg} 4 \cdots \mathrm{Cg} 3[1-x, 1-y, 2-z]$ of 3.5855(15) $\mathrm{A}$, again with better stacking of $\mathrm{Cg} 5 \cdots \mathrm{Cg} 3$ as in 2 (Table S6, ESI $\dagger$ ).

Interestingly, only two ionic chloride structures of molybdenum complexes with ONO-donor ligands were found in the Cambridge Structural Database: ${ }^{18}$ cis-dioxido-methanol-( $N$-salicylidene- $N N^{\prime}$-(pyridinium)ethylidenehydrazone)-molybdenum(vi) chloride, ${ }^{10 b}$ and 
(a)

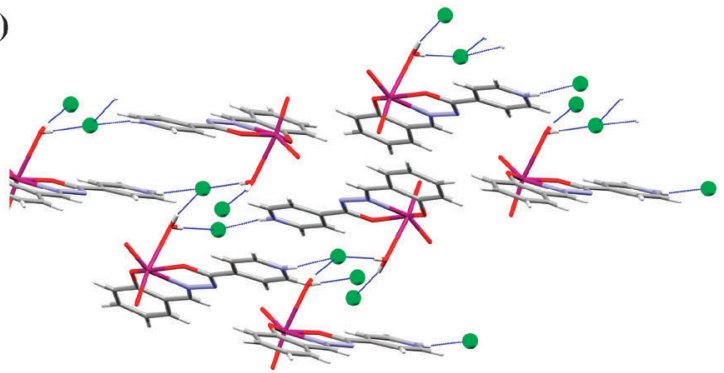

(b)

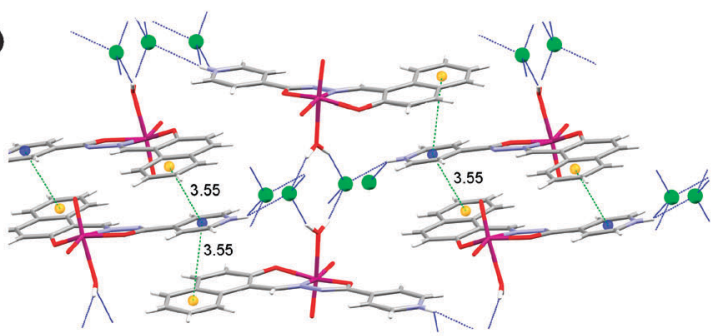

(c)

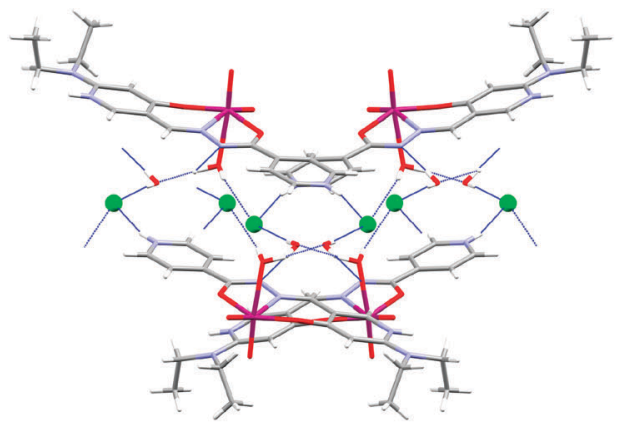

Fig. 7 Nonbonding interactions connecting the ions into supramolecular motifs in $\mathbf{1 a}$ (a), $\mathbf{2 a}$ (b) and $\mathbf{3 a} \cdot \mathrm{H}_{2} \mathrm{O}$ (c). Hydrogen bonds are shown by blue dotted lines. The distance between centroids (green dashed lines) is in $\AA$.

(3-(salicylideneiminato)-2-(2-hydroxyphenyl)piperidinum-3carboxylato- $N, O, O^{\prime}$ )-methanol-dioxido-molybdenum(vi) chloride methanol solvate. ${ }^{10 a}$

Complexes $\mathbf{5}$ and $\mathbf{6}$ are deprotonated and chloride free $\mathbf{2}$ and 3 , respectively. In 5 the molecules are connected by hydrogen bonds into helical chains around the $4_{1}$ axis involving the methanol hydroxyl group and the deprotonated isonicotinyl nitrogen $\mathrm{O}-\mathrm{H} \cdots \mathrm{N}$ of $2.709(3) \AA$. The chains are connected by $\pi \cdots \pi$ interactions between the isonicotinyl and naphthaldehyde moieties with the strongest interactions between centroids Cg3 3 Cg5 $5[1-x,-y,-z]$ of 3.7563(15) $\AA$ suggesting that $\pi \cdots \pi$ interactions are weaker than in 2 (Fig. $8 \mathrm{a}$ and Table S6, ESI†). The only complex with no classical hydrogen bonds within this study is $\mathbf{6}$. The polymeric zig-zag chains are parallel to the $b$-axis (Fig. 8(b)). There are only van der Waals interactions between the chains. Coordination polymers with such linking through the nitrogen atom are very rare. A methanol solvate of $\mathbf{6}$ has been recently reported. ${ }^{9}$ It is also polymeric without hydrogen bonds between the solvent methanol molecules and the complex molecules. Interestingly, the two diethyl substituents are in a trans position whereas in all our structures they are cis to each

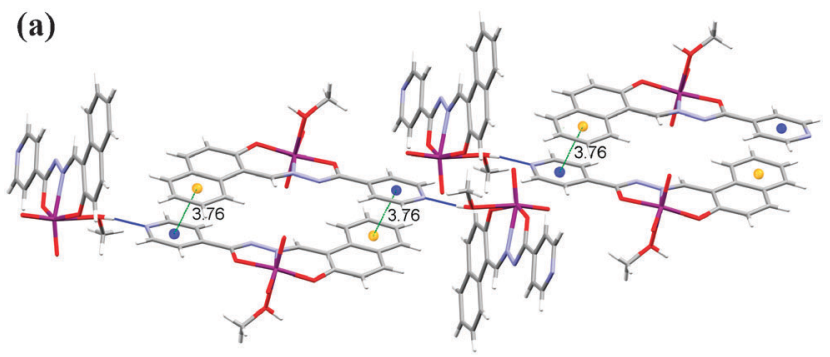

(b)

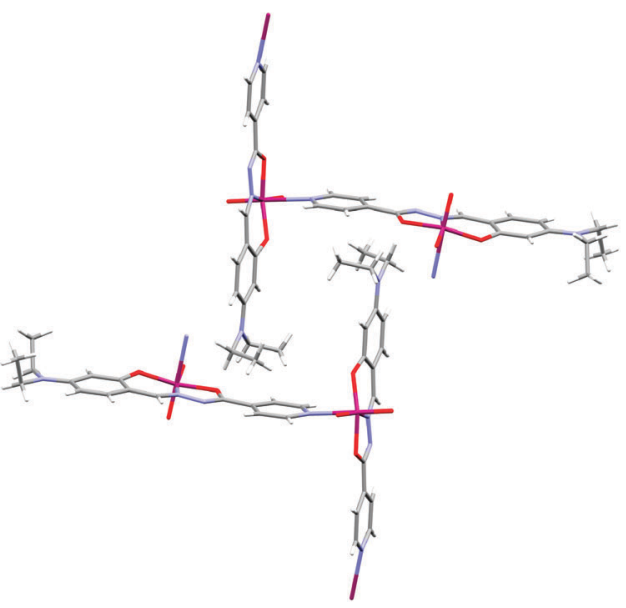

Fig. 8 (a) Nonbonding interactions connecting the molecules into a 3D-network in $\mathbf{5}$. Hydrogen bonds are shown by blue dotted lines. The distance between centroids is in $\AA$; (b) two polymeric chains in $\mathbf{6}$.

other. Two other coordination polymers with the linker being the isonicotinyl moiety have been described previously. ${ }^{6,7}$ Packing diagrams of all complexes are given in Fig. S4 to S11, see ESI. $\dagger$

\section{Conclusions}

Substitution of the chloride ligands in $\mathrm{MoO}_{2} \mathrm{Cl}_{2}$ by the corresponding aroylhydrazone ligand $\mathrm{H}_{2} \mathrm{~L}^{\mathrm{R}}$ in methanol gives rise to formation of the mononuclear complexes $\left[\mathrm{MO}_{2}\left(\mathrm{HL}^{\mathrm{R}}\right)(\mathrm{MeOH})\right] \mathrm{Cl}(\mathbf{1}-\mathbf{3})$. In these compounds, the ligands $\left(\mathrm{HL}^{\mathrm{R}}\right)^{-}$are coordinated to the cis- $\left\{\mathrm{MoO}_{2}\right\}^{2+}$ core via the ONO donor atoms. We have shown that mononuclear complexes 1-3 can be readily deprotonated into the mononuclear $\left[\mathrm{MoO}_{2}\left(\mathrm{HL}^{\mathrm{R}}\right)(\mathrm{MeOH})\right](\mathbf{4}$ and 5) and/or polynuclear $\left[\mathrm{MoO}_{2}\left(\mathrm{~L}^{\mathrm{R}}\right)\right]_{n}(\mathbf{6})$ complexes by using $\mathrm{Et}_{3} \mathrm{~N}$ as a base, either by a conventional solution-based method or by a mechanochemical approach. Compounds 4-6 can be prepared alternatively without using a base by photoassisted deprotonation of the corresponding complexes 1-3. The introduction of UV light enables deprotonation without altering the tridentate presentation of donor atoms characteristic of this class of chelating agent. In the polynuclear complex $\mathbf{6}$, the isoniazid ligand is coordinated instead of the solvent molecule.

A diversity of supramolecular achitectures are formed in the complexes by non-bonding interactions, especially hydrogen bonds and $\pi \cdots \pi$ interactions. In the singly-deprotonated ionic complexes 1-3 and 1a-3a. $\mathbf{H}_{2} \mathbf{O}$ the protonated nitrogen atom of the isonicotinyl moiety and the coordinated solvent molecules 
are the hydrogen bond donors while the chloride ion is the main hydrogen bond acceptor (of two hydrogen bonds in 1-3, three in $\mathbf{1 a}$ and $\mathbf{3} \mathbf{a} \cdot \mathbf{H}_{2} \mathbf{O}$, and four in $\mathbf{2 a}$ ). $\pi \cdots \pi$ interactions are found in all of these complexes except $1 \mathbf{a}$ and $\mathbf{3 a} \cdot \mathbf{H}_{2} \mathbf{O}$. The main motifs formed are either layers (1) or chains $(2,3)$, whereas in 1a, 2a and $\mathbf{3 a} \cdot \mathbf{H}_{2} \mathbf{O}$ which has an extra hydrogen bond donor (coordinated water instead of methanol) there are either layers (1a and 3a. $\mathbf{H}_{2} \mathbf{O}$ ) or a 3D-network (2a). Quite different is the doubly-deprotonated molecular complex $\mathbf{5}$ where the molecules are connected by hydrogen bonds into helical chains around the $4_{1}$ axis involving the methanol hydroxyl group and the deprotonated isonicotinyl nitrogen. Weak $\pi \cdots \pi$ interactions interconnect the chains into a 3D-network. As expected, the complexes with coordinated solvent molecules have low thermal stability. In the structure of the heteronuclear complex 6 there are only van der Waals interactions between the chains. This is also the thermally most stable complex since it is polymeric without coordinated solvent molecules.

\section{Experimental section}

Preparative part. Ligands $\mathrm{H}_{2} \mathrm{~L}^{\mathrm{SIH}}, \mathrm{H}_{2} \mathrm{~L}^{\mathrm{NIH}}$, and $\mathrm{H}_{2} \mathrm{~L}^{\mathrm{Et} \mathrm{NSIH}}$ were prepared by the reaction of isonicotinyl hydrazine ("isoniazid") with an appropriate aldehyde according to the procedures described in the literature. ${ }^{16}$ The starting $\mathrm{MoO}_{2} \mathrm{Cl}_{2}$ was prepared as described in the literature. ${ }^{19}$ Methanol was dried using magnesium turnings and iodine and then distilled.

\section{Synthesis of 1-3}

$\mathrm{MoO}_{2} \mathrm{Cl}_{2}(0.06 \mathrm{~g}, 0.30 \mathrm{mmol})$ was added to a solution of $\mathrm{H}_{2} \mathrm{~L}^{\mathrm{R}}$ $(0.30 \mathrm{mmol})$ in dry methanol $(25 \mathrm{~mL})$ at room temperature and was stirred for four hours. The solution was left at room temperature for a few days and the resulting crystalline substance was filtered, rinsed with cold methanol and dried in a desiccator up to the constant mass. The crystals lose methanol molecules upon prolonged standing at room temperature. Therefore after filtration, the crystals were transferred into a desiccator and then placed in a freezer (at $-15{ }^{\circ} \mathrm{C}$ ).

$\left[\mathrm{MoO}_{2}\left(\mathbf{H L}^{\mathrm{SIH}}\right)(\mathbf{M e O H})\right] \mathbf{C l}(\mathbf{1})$. Orange product. Yield: $80 \mathrm{mg}$, $62 \%$. Calc. for $\mathrm{C}_{14} \mathrm{H}_{14} \mathrm{ClMoN}_{3} \mathrm{O}_{5}$ : C, 38.6; H, 3.2; N, 9.6. Found: C, 38.3; H, 2.9; N, 9.6\%. TG: calc. for $\mathrm{MeOH} \mathrm{7.35 \% ;} \mathrm{found}$ $7.75 \%$, calc. for $\mathrm{HCl} 8.4 \%$, found $8.8 \%$; calc. for $\mathrm{MoO}_{3} 33.0$, found 32.65\%. Selected IR data $\left(\mathrm{cm}^{-1}\right): 1638(\mathrm{C}=\mathrm{N})_{\mathrm{py}}, 1609$ $(\mathrm{C}=\mathrm{N}), 1545\left(\mathrm{C}-\mathrm{O}_{\text {phenolate }}\right), 1342\left(\mathrm{C}-\mathrm{O}_{\text {isonicotinic }}\right), 1037\left(\mathrm{C}-\mathrm{O}_{\mathrm{MeOH}}\right)$, $944\left(\mathrm{MoO}_{2}\right), 918,906\left(\mathrm{O}=\mathrm{Mo}-\mathrm{O}_{\mathrm{MeOH}}\right)$.

$\left[\mathrm{MoO}_{2}\left(\mathrm{HL}^{\mathbf{N I H}}\right)(\mathbf{M e O H})\right] \mathrm{Cl}$ (2). Red product. Yield: $130 \mathrm{mg}$, $89 \%$. Calc. for $\mathrm{C}_{18} \mathrm{H}_{16} \mathrm{ClMoN}_{3} \mathrm{O}_{5}$ : C, 44.5; H, 3.3; N, 8.65. Found: C, 44.8; H, 3.25; N, 8.8\%. TG: calc. for $\mathrm{MeOH} \mathrm{6.6 \% ,} \mathrm{found} \mathrm{6.3 \% ;}$ calc. for $\mathrm{HCl} 7.5 \%$, found 7.3\%; calc. for $\mathrm{MoO}_{3}$ 29.6, found 30.6\%. Selected IR data $\left(\mathrm{cm}^{-1}\right): 1635(\mathrm{C}=\mathrm{N})_{\mathrm{py}}, 1616(\mathrm{C}=\mathrm{N})$,

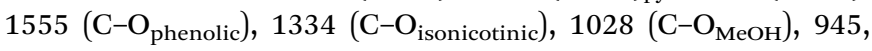
$925\left(\mathrm{MoO}_{2}\right), 907\left(\mathrm{O}=\mathrm{Mo}-\mathrm{O}_{\mathrm{MeOH}}\right)$.

$\left[\mathrm{MoO}_{2}\left(\mathrm{HL}^{\mathrm{Et}_{2} \mathbf{N S I H}}\right)(\mathbf{M e O H})\right] \mathbf{C l}$ (3). Dark purple-red product. Yield: $99 \mathrm{mg}, 67 \%$. Calc. for $\mathrm{C}_{18} \mathrm{H}_{23} \mathrm{ClMoN}_{4} \mathrm{O}_{5}$ : C, 42.7; H, 4.6; N, 11.1. Found: C, 42.7; H, 4.85; N, 11.0\%. TG: calc. for $\mathrm{MeOH}$
6.32 and calc. for $\mathrm{HCl} 7.2 \%$, found 13.5\%; calc. for $\mathrm{MoO}_{3} 28.40$, found 28.65\%. Selected IR data $\left(\mathrm{cm}^{-1}\right): 1632(\mathrm{C}=\mathrm{N})_{\mathrm{py}}, 1608$ $(\mathrm{C}=\mathrm{N}), 1547\left(\mathrm{C}-\mathrm{O}_{\text {phenolate }}\right), 1327\left(\mathrm{C}-\mathrm{O}_{\text {isonicotinic }}\right), 1027\left(\mathrm{C}-\mathrm{O}_{\mathrm{MeOH}}\right)$, 944, $929\left(\mathrm{MoO}_{2}\right), 907\left(\mathrm{O}=\mathrm{Mo}-\mathrm{O}_{\mathrm{MeOH}}\right)$.

\section{Conversion of 1-3 to 1a-3a}

Samples of 1-3 were exposed to water vapour under ambient conditions.

$\left[\mathrm{MoO}_{2}\left(\mathrm{HL}^{\mathrm{SIH}}\right)\left(\mathrm{H}_{2} \mathrm{O}\right)\right] \mathbf{C l}$ (1a). Orange product. Crystals were obtained after recrystallisation from wet methanol. Calc. for $\mathrm{C}_{13} \mathrm{H}_{12} \mathrm{ClMoN}_{3} \mathrm{O}_{5}$ : C, 37.0; H, 2.9; N, 10.0. Found: C, 36.8; H, 3.2 ; N, 9.5\%. TG: calc. for $\mathrm{H}_{2} \mathrm{O} 4.3 \%$, found $4.6 \%$, TG: calc. for $\mathrm{HCl} 8.65 \%$, found $9.05 \%$, calc. for $\mathrm{MoO}_{3} 34.1$, found $33.85 \%$. Selected IR data $\left(\mathrm{cm}^{-1}\right): 1637(\mathrm{C}=\mathrm{N})_{\mathrm{py}}, 1605(\mathrm{C}=\mathrm{N}), 1549$ (C-O $\mathrm{O}_{\text {phenolate }}$ ), 1347 (C-O $\mathrm{O}_{\text {isonicotinic }}$ ), $943\left(\mathrm{MoO}_{2}\right), 910(\mathrm{O}=\mathrm{Mo}-\mathrm{O})$.

$\left[\mathrm{MoO}_{2}\left(\mathbf{H L}^{\mathbf{N I H}}\right)\left(\mathbf{H}_{2} \mathrm{O}\right)\right] \mathrm{Cl}$ (2a). Red product. Crystals were obtained after recrystallisation from wet acetonitrile. Calc. for $\mathrm{C}_{17} \mathrm{H}_{14} \mathrm{ClMoN}_{3} \mathrm{O}_{5}$ : C, 43.3; H, 3.0; N, 8.9. Found: C, 42.8; H, 3.1; N, 8.7\%. TG: calc. for $\mathrm{H}_{2} \mathrm{O} 3.8 \%$, found $4.2 \%$; calc. for $\mathrm{HCl}$ $7.7 \%$, found $7.3 \%$; calc. for $\mathrm{MoO}_{3} 30.5$, found $30.2 \%$. Selected IR data $\left(\mathrm{cm}^{-1}\right): 1620(\mathrm{C}=\mathrm{N})_{\mathrm{py}}, 1600(\mathrm{C}=\mathrm{N}), 1547\left(\mathrm{C}-\mathrm{O}_{\text {phenolate }}\right)$, 1332 (C-O $\left.\mathrm{O}_{\text {isonicotinic }}\right), 935\left(\mathrm{MoO}_{2}\right), 907(\mathrm{O}=\mathrm{Mo}-\mathrm{O})$.

$\left[\mathrm{MoO}_{2}\left(\mathrm{HL}^{\mathrm{Et}_{2} \mathrm{NSIH}}\right)\left(\mathrm{H}_{2} \mathrm{O}\right)\right] \mathbf{C l} \cdot \mathrm{H}_{2} \mathrm{O}\left(3 \mathrm{a} \cdot \mathrm{H}_{2} \mathrm{O}\right)$. Dark-red product. Crystals of $\mathbf{3 a} \cdot \mathbf{H}_{2} \mathbf{O}$ were obtained after recrystallisation from wet acetonitrile. Calc. for $\mathrm{C}_{17} \mathrm{H}_{23} \mathrm{ClMoN}_{4} \mathrm{O}_{6}$ : C, 40.0; H, 4.5; N, 11.0. Found: $\mathrm{C}, 39.5 ; \mathrm{H}, 4.25 ; \mathrm{N}, 10.7 \%$. TG: calc. for $\mathrm{H}_{2} \mathrm{O} 7.05 \%$, found $6.8 \%$; calc. for $\mathrm{HCl} 7.1 \%$, found $6.5 \%$; calc. for $\mathrm{MoO}_{3}$ 28.2, found $28.4 \%$. Selected IR data $\left(\mathrm{cm}^{-1}\right): 1637(\mathrm{C}=\mathrm{N})_{\mathrm{py}}, 1613$ $(\mathrm{C}=\mathrm{N}), 1549\left(\mathrm{C}-\mathrm{O}_{\text {phenolate}}\right), 1327\left(\mathrm{C}-\mathrm{O}_{\text {isonicotinic }}\right), 938\left(\mathrm{MoO}_{2}\right)$, $906(\mathrm{O}=\mathrm{Mo}-\mathrm{O})$.

\section{Deprotonation of 1-3}

Method A: base assisted solution-phase method. A solution of $\mathrm{Et}_{3} \mathrm{~N}(15 \mu \mathrm{L})$ in dry methanol $(25 \mathrm{~mL})$ was added to a stirred solution of $\left[\mathrm{MoO}_{2}\left(\mathrm{HL}^{\mathrm{R}}\right)(\mathrm{MeOH})\right] \mathrm{Cl}(\mathbf{1}-3)(0.11 \mathrm{mmol})$ in dry methanol $(25 \mathrm{~mL})$. The solution was left at room temperature for a few days. The obtained product was filtered and dried.

Method B: base assisted mechanochemical method. A Retsch MM200 grinder mill operating at $25 \mathrm{~Hz}$ frequency was used for the synthesis. A mixture of $\mathrm{Et}_{3} \mathrm{~N}(35 \mu \mathrm{L}),\left[\mathrm{MoO}_{2}\left(\mathrm{HL}^{\mathrm{R}}\right)\right.$ $(\mathrm{MeOH})] \mathrm{Cl}(\mathbf{1 - 3}),(0.22 \mathrm{mmol})$ and methanol $(15 \mu \mathrm{L})$ was placed with two $7 \mathrm{~mm}$ grinding balls in a $10 \mathrm{~mL}$ stainless steel jar and milled for $30 \mathrm{~min}$. The resulting substance was rinsed with water and dried.

Method C: UV-light assisted method. A solution of $\left[\mathrm{MoO}_{2}\left(\mathrm{HL}^{\mathrm{R}}\right)(\mathrm{MeOH})\right] \mathrm{Cl}(\mathbf{1 - 3})(0.11 \mathrm{mmol})$ in $\mathrm{MeOH}(25 \mathrm{~mL})$ in a quartz flask was irradiated with UV-light of wavelength $254 \mathrm{~nm}$ for two hours. The solution was slowly evaporated at room temperature. After a few days the obtained precipitate was collected by filtration, rinsed with cold methanol and dried.

$\left[\mathbf{M o O}_{2}\left(\mathbf{L}^{\mathbf{S I H}}\right)(\mathbf{M e O H})\right](4)$. Orange product. Yield: $35 \mathrm{mg}, 81 \%$ (method A); $32 \mathrm{mg}, 74 \%$ (method B); $80 \mathrm{mg}, 93 \%$ (method C). Calc. for $\mathrm{C}_{14} \mathrm{H}_{13} \mathrm{MoN}_{3} \mathrm{O}_{5}: \mathrm{C}, 42.1 ; \mathrm{H}, 3.3 ; \mathrm{N}, 10.5$. Found: $\mathrm{C}, 41.85 ; \mathrm{H}$, 3.55; N, $10.3 \%$. TG: calc. for $\mathrm{MeOH} 8.2 \%$, found $8.8 \%$; calc. for $\mathrm{MoO}_{3} 36.1 \%$, found $35.8 \%$. Selected IR data $\left(\mathrm{cm}^{-1}\right): 1620(\mathrm{C}=\mathrm{N})_{\mathrm{py}}$, 
$1601(\mathrm{C}=\mathrm{N}), 1553$ (C-O $\left.\mathrm{O}_{\text {phenolate}}\right), 1338$ (C-O $\left.\mathrm{O}_{\text {isonicotinic }}\right), 1062$ $\left(\mathrm{C}-\mathrm{O}_{\mathrm{MeOH}}\right)$, 938, $931\left(\mathrm{MoO}_{2}\right), 912,902\left(\mathrm{O}=\mathrm{Mo}-\mathrm{O}_{\mathrm{MeOH}}\right)$.

$\left[\mathrm{MoO}_{2}\left(\mathbf{L}^{\mathbf{N I H}}\right)(\mathbf{M e O H})\right]$ (5). Red product. Yield: $38 \mathrm{mg}, 77 \%$ (method A); $40 \mathrm{mg}, 82 \%$ (method B); $84 \mathrm{mg}, 86 \%$ (method $\mathrm{C})$. Calc. for $\mathrm{C}_{18} \mathrm{H}_{15} \mathrm{MoN}_{3} \mathrm{O}_{5}$ : C, 48.1; H, 3.4; N, 9.35. Found: C, 47.8; $\mathrm{H}, 3.3$; N, 9.5\%. TG: calc. for $\mathrm{MeOH} 7.1 \%$, found 6.8\%; calc. for $\mathrm{MoO}_{3} 32.0 \%$, found 32.3\%. Selected IR data $\left(\mathrm{cm}^{-1}\right): 1622$ $(\mathrm{C}=\mathrm{N})_{\mathrm{py}}, 1600(\mathrm{C}=\mathrm{N}), 1550\left(\mathrm{C}-\mathrm{O}_{\text {phenolate }}\right), 1334\left(\mathrm{C}-\mathrm{O}_{\text {isonicotinic }}\right)$, $1062\left(\mathrm{C}-\mathrm{O}_{\mathrm{MeOH}}\right), 938,927\left(\mathrm{MoO}_{2}\right), 910\left(\mathrm{O}=\mathrm{Mo}-\mathrm{O}_{\mathrm{MeOH}}\right)$.

$\left[\mathbf{M o O}_{2}\left(\mathbf{L}^{\mathbf{E t}_{2} \mathbf{N S I H}}\right)\right]_{\boldsymbol{n}}$ (6). Dark red product. Yield: $35 \mathrm{mg}, 73 \%$ (method A); $41 \mathrm{mg}, 85 \%(\operatorname{method} \mathrm{B}) ; 82 \mathrm{mg}, 65 \%$ (method $\mathrm{C})$. Calc. for $\mathrm{C}_{17} \mathrm{H}_{18} \mathrm{MoN}_{4} \mathrm{O}_{4}$ : C, 46.6; $\mathrm{H}, 4.1 ; \mathrm{N}, 12.8$. Found: C, 46.2; $\mathrm{H}, 4.3$; N, $12.7 \%$. TG: calc. for $\mathrm{MoO}_{3} 32.8 \%$, found $33.1 \%$. Selected IR data $\left(\mathrm{cm}^{-1}\right): 1616(\mathrm{C}=\mathrm{N}), 1564\left(\mathrm{C}-\mathrm{O}_{\text {phenolate }}\right), 1333$ $\left(\mathrm{C}-\mathrm{O}_{\text {isonicotinyl }}\right), 938\left(\mathrm{MoO}_{2}\right), 907(\mathrm{O}=\mathrm{Mo}-\mathrm{N})$.

Physical methods. Elemental analyses were provided by the Analytical Services Laboratory of the Ruđer Bokovic Institute, Zagreb. Thermogravimetric (TG) analysis was carried out using a Mettler TG 50 thermobalance using alumina $(70 \mu \mathrm{L})$ crucibles. All experiments were recorded in a dynamic atmosphere with a flow rate of $200 \mathrm{~cm}^{3} \mathrm{~min}^{-1}$. Heating rates of $5 \mathrm{~K} \mathrm{~min}^{-1}$ were used for all investigations. Differential scanning calorimetry (DSC) measurements were carried out using a Mettler-Toledo DSC823e calorimeter and analyzed using the Mettler $\operatorname{STAR}^{\mathrm{e}}$ 9.01. software. Fourier Transform Infrared spectra (FT-IR) were recorded in $\mathrm{KBr}$ pellets using a Perkin-Elmer 502 spectrophotometer. Spectra were recorded in the spectral range between 4500 and $450 \mathrm{~cm}^{-1}$.

All the ${ }^{1} \mathrm{H}$ NMR spectra were recorded on a Bruker Avance 300 NMR spectrometer operating at $300 \mathrm{MHz}$ for ${ }^{1} \mathrm{H}$ and $75 \mathrm{MHz}$ for ${ }^{13} \mathrm{C}$ using a $\mathrm{C} / \mathrm{H}$ dual $5 \mathrm{~mm}$ probe. DMSO- $d_{6}$ was used as the solvent and TMS as the internal standard. Proton spectra with a spectral width of $6200 \mathrm{~Hz}$ and a digital resolution of $0.09 \mathrm{~Hz}$ per point were measured with 16-32 scans. APT spectra with spectral widths of $18030 \mathrm{~Hz}$ were collected with 256-1024 scans. The digital resolution was $0.11 \mathrm{~Hz}$ per point. In the gCOSY experiment 2046 points in the $f_{2}$ dimension and 256 increments in the $f_{1}$ dimension were used. For each increment 4 scans and a spectral width of $3086 \mathrm{~Hz}$ were applied. The digital resolution was $3.03 \mathrm{~Hz}$ and $24.39 \mathrm{~Hz}$ per point in $f_{2}$ and $f_{1}$ dimensions, respectively. Typical spectral conditions for gHSQC and gHMBC spectra were as follows. The spectral width was $2994 \mathrm{~Hz}$ in $f_{2}$ and $16605 \mathrm{~Hz}$ in $f_{1}$ dimension for both experiments. $2 \mathrm{k}$ data points were applied in the time domains and for each data set 256 and 128 increments were collected for gHSQC and gHMBC spectra, respectively. The resulting digital resolution was $2.94 \mathrm{~Hz}$ per point in $f_{2}$ dimension and $125.1 \mathrm{~Hz}$ and $250.0 \mathrm{~Hz}$ per point in $f_{1}$ dimension in gHSQC and gHMBC spectra, respectively. ${ }^{1} \mathrm{H}$ and ${ }^{13} \mathrm{C}$ chemical shifts of 1-6 are given in Tables S1-S3 (see ESI $\dagger$ ).

\section{X-Ray crystallography}

Powder diffraction. The powder X-ray diffraction data were collected using the Panalytical X'Change powder diffractometer in the Bragg-Brentano geometry using $\mathrm{Cu} \mathrm{K}_{\alpha}$ radiation. The sample was placed on a Si sample holder. Patterns were collected in the range of $2 \theta=5-50^{\circ}$ with a step size of $0.03^{\circ}$ and at $1.5 \mathrm{~s}$ per step. The data were collected and visualized using the X'Pert programs Suite. $^{20}$

Single crystal diffraction. All single crystal X-ray diffraction measurements were performed on an Oxford Diffraction Xcalibur 3 CCD diffractometer with graphite-monochromated Mo $\mathrm{K}_{\alpha}$ radiation $(\lambda=0.71073 \AA$ ). Each single crystal was glued onto a glass fiber and the data were collected at room temperature with exceptions of $\mathbf{1}$ and 2a for which data were collected in nitrogen vapour at $150 \mathrm{~K}$. Data reduction was performed using the CrysAlis software package. ${ }^{21}$ Solution, refinement and analysis of the structures was done by the programs integrated in the WinGX program system. ${ }^{22}$ The structures were solved using SHELXS ${ }^{23}$ by the Patterson method. The refinement procedure was performed by the full-matrix least-squares method based on $F^{2}$ against all reflections using SHELXL-97. ${ }^{24}$ All non-hydrogen atoms were refined anisotropically. The $-\mathrm{CH}_{2} \mathrm{CH}_{3}$ group in 3 was found to be disordered over two occupation sites that refined to $0.517(6)$ and $0.483(6)$. All hydrogen atoms were located in the difference Fourier maps. Because of poor geometry for some of them they were placed in calculated positions and refined using the riding model. Geometrical calculations were done using PLATON. ${ }^{25}$ Structure drawings were prepared using PLATON and MERCURY ${ }^{26}$ programs. The crystallographic data are summarized in Table 3.

\section{Acknowledgements}

Financial support for this research was provided by Ministry of Science and Technology of the Republic of Croatia.

\section{Notes and references}

1 (a) S. Banerjee, A. Ray, S. Sen, S. Mitra, D. L. Hughes, R. J. Butcher, S. R. Batten and D. R. Turner, Inorg. Chim. Acta, 2008, 361, 2692; (b) J. G. Vos and M. T. Pryce, Coord. Chem. Rev., 2010, 254, 2519; (c) A. Kobayashi, D. Yamamoto, H. Horiki, K. Sawaguchi, T. Matsumoto, K. Nakajima, H.-C. Chang and M. Kato, Inorg. Chem., 2014, 53, 2573.

2 M. Chang, A. Kobayashi, K. Nakajima, H.-C. Chang and M. Kato, Inorg. Chem., 2011, 50, 8308.

3 (a) S. Taktak, W. Ye, A. M. Herrera and E. V. Rybak-Akimova, Inorg. Chem., 2007, 46, 2929; (b) M. Haga, M. Ali, S. Koseki, K. Fujimoto, A. Yoshimura, K. Nozaki, T. Ohno, K. Nakajima and D. Stufkens, Inorg. Chem., 1996, 35, 3335; (c) S. Klein, W. G. Dougherty, W. S. Kassel, T. J. Dudley and J. J. Paul, Inorg. Chem., 2011, 50, 2754.

4 (a) S. M. Landge and I. Aprahamian, J. Am. Chem. Soc., 2009, 131, 18269; (b) X. Su, T. F. Robbins and I. Aprahamian, Angew. Chem., Int. Ed., 2011, 50, 1841.

5 (a) M. C. Rodríguez-Argüelles, S. Mosquera-Vázquez, P. Tourón-Touceda, J. Sanmartín-Matalobos, A. M. GarcíaDeibe, M. Belicchi Ferrari, G. Pelosi, C. Pelizzi and F. Zani, J. Inorg. Biochem., 2007, 101, 138; (b) D. S. Kalinowski, 
P. C. Sharpe, P. V. Bernhardt and D. R. Richardson, J. Med. Chem., 2008, 51, 331.

6 V. Vrdoljak, B. Prugovečki, D. Matković-Čalogović, R. Dreos, P. Siega and C. Tavagnacco, Cryst. Growth Des., 2010, 10, 1373.

7 V. Vrdoljak, B. Prugovečki, D. Matković-Čalogović, J. Pisk, R. Dreos and P. Siega, Cryst. Growth Des., 2011, 11, 1244.

8 V. Vrdoljak, B. Prugovečki, D. Matković-Čalogović, T. Hrenar, R. Dreos and P. Siega, Cryst. Growth Des., 2013, 13, 3773.

9 W. X. Xu and W. H. Li, Koord. Khim., 2012, 38, 98.

10 (a) M. Cindrić, G. Galin, D. Matković-Čalogović, P. Novak, T. Hrenar, I. Ljubić and T. K. Novak, Polyhedron, 2009, 28, 562; (b) H. X. Liu and X. M. Wang, Polyhedron, 1994, 13, 441.

11 (a) S. Gao, L.-H. Huo, H. Zhao and S. W. Ng, Acta Crystallogr., Sect. E: Struct. Rep. Online, 2004, 60, m1757; (b) Y.-L. Zhai, X.-X. Xu and X. Wang, Polyhedron, 1992, 11, 415; (c) H. D. Yin, M. Hong, G. Li and D. Q. Wang, J. Org. Chem., 2005, 690, 3714; (d) I. I. Seifullina, N. V. Shmatkova and Z. A. Starikova, Russ. J. Inorg. Chem., 2001, 46, 1150.

12 O. A. Rajan and A. Chakratvorty, Inorg. Chem., 1981, 20, 660.

13 M. R. Maurya, S. Agarwal, C. Bader and D. Rehder, Eur. J. Inorg. Chem., 2005, 147.

14 M. R. Maurya, S. Gopinathan, C. Gopinathan and R. C. Maurya, Polyhedron, 1993, 12, 159.
15 (a) K. Nakajima, K. Yokoyama, T. Kano and M. Kojima, Inorg. Chim. Acta, 1998, 282, 209; (b) J. M. Berg and R. H. Holm, Inorg. Chem., 1983, 22, 1768.

16 D. R. Richardson and P. V. Bernhardt, J. Biol. Inorg. Chem., 1999, 4, 266.

17 Y.-J. Xu, S. Zhao and S. Bi, Acta Crystallogr., Sect. E: Struct. Rep. Online, 2007, 63, o4633.

18 F. H. Allen, Acta Crystallogr., Sect. B: Struct. Sci., 2002, 58, 380 .

19 R. L. Graham and L. G. Helper, J. Phys. Chem., 1959, 63, 723.

20 X'Pert Software Suite, Version 1.3e, Panalytical B. V. Almelo, The Netherlands, 2001.

21 CrysAlisPro, Version 1.171.37.33, Agilent Technologies, (release 27-03-2014 CrysAlis171.NET).

22 L. J. Farrugia, J. Appl. Crystallogr., 1999, 32, 837.

23 G. M. Sheldrick, SHELXS97, Program for the Solution of Crystal Structures, University of Göttingen, Germany, 1997.

24 G. M. Sheldrick, Acta Crystallogr., Sect. A: Found. Crystallogr., 2008, 64, 112.

25 A. L. Spek, J. Appl. Crystallogr., 2003, 36, 7.

26 C. F. Macrae, I. J. Bruno, J. A. Chisholm, P. R. Edgington, P. McCabe, E. Pidcock, L. Rodriguez-Monge, R. Taylor, M. Towler, J. Van der Streek and P. A. Wood, J. Appl. Crystallogr., 2008, 41, 466. 